\title{
MECONIUM SAMPLES USED TO ASSESS INFANT EXPOSURE TO THE COMPONENTS OF ETS DURING PREGNANCY
}

\section{SYLWIA NARKOWICZ ${ }^{1}$, ŻANETA POLKOWSKA ${ }^{1}$, BOGUMIŁA KIEŁBRATOWSKA ${ }^{2}$, and JACEK NAMIEŚNIK ${ }^{1}$}

${ }^{1}$ Gdańsk University of Technology, Gdańsk, Poland

Department of Analytical Chemistry, Chemical Faculty

${ }^{2}$ Medical University of Gdańsk, Gdańsk, Poland

Department of Obstetrics

\begin{abstract}
Objectives: The aim of the study was to use meconium samples to assess fetal exposure to compounds present in environmental tobacco smoke (ETS). Material and Methods: In order to assess fetal exposure to toxic tobacco smoke compounds, samples of meconium from the offspring of women with different levels of tobacco smoke exposure, and the samples of saliva from the mothers were analyzed. Thiocyanate ion as a biomarker of tobacco smoke exposure, and other ions that are indices of such exposure were determined by means of ion chromatography. Results: The results of ion chromatography analysis of the meconium and maternal saliva samples for the presence of cations and anions (including thiocyanate ion) indicate that the concentration level of specific ions depends on the intensity of environmental tobacco smoke exposure of pregnant women. Conclusions: Based on the results, it can be concluded that meconium samples can be used to determine the substances from tobacco smoke. The results confirm the effect of smoking during pregnancy on the presence and content of substances from tobacco smoke.
\end{abstract}

Key words:

Environmental tobacco smoke, Infant exposure, Meconium, Saliva, Ion chromatography, Thiocyanate ion

\section{INTRODUCTION}

Tobacco and various alcoholic beverages are the most frequently consumed products that may have a negative impact on human health [1]. Tobacco smoking is a serious health problem, particularly in the case of pregnant women because there is a chance of negative effects in children exposed to tobacco smoke in utero [2].

A pregnant woman can either be exposed to tobacco smoke components by:
- active smoking (woman is mainly exposed to the mainstream smoke, which is absorbed through her mouth),

- or by being a passive smoker (women is exposed to the components of environmental tobacco smoke - ETS) [2].

Women may be exposed via being in the atmosphere of tobacco smoke at home and in the workplace. The law prohibits smoking in public places, but not all workplaces are non-smoking. In this case, when there are no

The research is funded by the Polish Ministry of Science and Higher Education within the "Iuventus Plus," project No. IP2014 032173. Project manager: Eng. Sylwia Narkowicz, Ph.D.

Received: June 25, 2014. Accepted: January 24, 2015.

Corresponding author: S. Narkowicz, Gdańsk University of Technology, Department of Analytical Chemistry, Chemical Faculty, Narutowicza 11/12, Gdańsk 80-233, Poland (e-mail: sylwianarkowicz@10g.pl). 
internal regulations, women at childbearing age and during pregnancy are exposed to the harmful substances contained in tobacco smoke [3].

The effects of exposure to tobacco smoke and ETS on the course of pregnancy and delivery include [1-7]:

- Neurodevelopmental and behavioural disturbances in their children. These disturbances are assumed to be due to changes in a child's brain following fetal hypoxia. Carbon monoxide is responsible for this as it raises the blood level of carboxyhaemoglobin, as well as nicotine and other compounds reducing the flow of blood in the foetus.

- The thiocyanate ion, a metabolite of cyanide ions, inhibits iodine capture, which may inhibit proper development of the brain and nervous system in infants. Iodine levels in milk samples collected from women actively smoking during their pregnancies were as much as $52 \%$ lower in comparison with the corresponding levels in milk from the non-smoking pregnant women.

- Cadmium can accumulate in placental tissue and limit fetal growth. Smoking in mothers-to-be causes thickening of the trophoblastic basement membrane and reduces placental vascularisation. Further consequences of fetal exposure to the toxic compounds in ETS become apparent in a child's later development: hyperactivity, reduced concentration, weak reaction to auditory stimuli in infants in the 1st week of life, lower intelligence at pre-school age. Fetal exposure to nicotine can also lead to addictive behaviours, and thus, to smoking in adult life.

- The action of irritants present in ETS may lead to chronic inflammation of child's respiratory tract, which in turn may cause asthma. Epidemiological studies have demonstrated that maternal smoking increases the risk of asthma development already in the 1st year of life.

Exposure to one of the tobacco smoke streams leads to the absorption by the pregnant woman's body of over 4000 compounds, many of them toxic, such as: cyanides, nitrosamines, phenols [8-14].

Toxic compounds present in ETS are absorbed into the human body via skin and respiratory tract. The burden of toxic substances depends on the individual susceptibility and sensitivity of a person, the physical and chemical properties of compounds and their metabolism. The compounds may either accumulate in tissues or be eliminated from the body unchanged or as metabolites. Excretion of toxic substances can occur via urine, saliva, sweat, feces and breast milk [15].

Exposure to toxic substances during pregnancy may cause absorption of such substances into the body followed by their transport via the circulatory system to various internal organs and therefore, can result in crossing the placental barrier [16]. This leads to fetal exposure to toxic substances. Unlike the body of an adult human [6], a fetal organism is not fully adapted to metabolize toxic compounds and therefore, exposure to toxins constitutes a serious risk to its health.

In the case of fetal exposure to tobacco smoke components, meconium is the perfect biological material to be used for determination of biomarkers of gestational exposure to tobacco smoke. Meconium is the 1st stool passed by a newborn infant. It is non-odorous, thick, sticky and dark green in color. Meconium starts to collect in the fetal intestines at around the 12th week of gestation, which coincides with ingestion of amniotic fluid by the fetus. It is easy and non-invasive to collect.

Meconium has a long historical record of prenatal exposure to certain drugs of abuse. It can account for the 2nd and 3rd trimester of gestation [7]. Additionally, it allows to detect maternal exposure to toxic compounds during the last 20 weeks of gestation. Meconium consists of water, epithelial cells of the intestine, squamous epithelial cells, lanugo hair, amniotic fluid, bile acids, salts, phospholipase A2, interleukin-8, glycoproteins, lipids, proteases, cholesterol, sterols, blood type precursors, 
enzymes, mucopolysacharides, sugars, fats, proteins and metals [15,17-19].

The 1st studies on the content of toxic compounds, such as narcotics, in meconium samples were published in 1989 [19]. Further reports dealt, inter alia, with determining caffeine and cotinine in meconium samples by means of high-performance liquid chromatography (HPLC) [17] (caffeine: $10-45 \mathrm{ng} / \mathrm{g}$, cotinine: $20-86 \mathrm{ng} / \mathrm{g}$ [19]). In literature there is no information on the studies of tobacco smoke exposure in pregnant women and their offspring based on biomarkers in the collected samples of biological material. Such biomarkers are nicotine, thiocyanate ion and carboxyhemoglobine [20,21].

In this work the ion chromatography method for determining thiocyanate in meconium samples collected from the newborns whose mothers were exposed to different tobacco smoke levels, as well as the obtained research results, are presented. Thiocyanate ion has a long halflife time (6 days), which allows to assess fetal exposure to tobacco smoke during pregnancy. The previously conducted studies indicate that the thiocyanate ion can be determined in biological fluids using ion chromatography. It was determined in samples of saliva (concentration range: heavy smokers $0.015-0.847 \mathrm{mg} / \mathrm{g}, 0.046-0.7 \mathrm{mg} / \mathrm{g}$ moderate smokers, passive smokers $0.046-0.277 \mathrm{mg} / \mathrm{g}$ ) and in samples of semen (concentration range: heavy smokers $0.00004-0.058 \mathrm{mg} / \mathrm{g}$, moderate smokers 0.00008 $0.043 \mathrm{mg} / \mathrm{g}$, passive smokers $0.00004-0.028 \mathrm{mg} / \mathrm{g}$ ) [22,23]. Moreover, the results on thiocyanate ion determination in the samples of saliva collected from the mothers, Pearson's correlation coefficient values for the relationships between ion concentrations in the samples of meconium and maternal saliva and F-Snedecor and t-students test to ion concentrations in meconium samples are reported. The strongest correlations were present between ions in meconium samples collected from infants whose mothers smoked during pregnancy. Also in saliva samples, the strongest correlations were present between ions collected from mothers who smoked during pregnancy.

The aim of the study was to use meconium samples collected from newborn babies and saliva collected from their mothers and based on it to assess fetal exposure to components present in tobacco smoke.

\section{MATERIAL AND METHODS \\ Reagents}

The following reference standards were used: Dionex (Sunnyvale, CA) Combined Seven Anion Standard II (F-: $20 \mathrm{mg} / \mathrm{l}^{-} \mathrm{Cl}^{-}, \mathrm{NO}_{2}^{-}, \mathrm{NO}_{3}^{-}, \mathrm{SO}_{4}^{2-}: 100 \mathrm{mg} / \mathrm{l}$; $\left.\mathrm{PO}_{4}^{3-}: 200 \mathrm{mg} / \mathrm{l}\right)$, Dionex Combined Six Cation Standard II $\left(\mathrm{Li}^{+}: 50 \mathrm{mg} / \mathrm{l} ; \mathrm{NH}_{4}^{+}, \mathrm{Mg}^{2+}: 250 \mathrm{mg} / \mathrm{l}\right.$; $\left.\mathrm{Na}^{2+}: 200 \mathrm{mg} / \mathrm{l} ; \mathrm{K}^{+}: 500 \mathrm{mg} / \mathrm{l} ; \mathrm{Ca}^{2+}: 500 \mathrm{mg} / \mathrm{l}\right)$ and Merck (Darmstadt, Germany) $\mathrm{NH}_{4} \mathrm{SCN} 0.1 \mathrm{~mol} / 1$. Methanesulfopnic acic was supplied by Sigma-Aldrich (Schnelldorf, Germany), while sodium carbonate and sodium hydrogen carbonate by Merck. Ultrapure deionized water was obtained by means of Milli-Q Gradient A10 system (resistivity $18.2 \mathrm{M} \Omega \mathrm{cm}, 25^{\circ} \mathrm{C}$ ).

\section{Sample collection and preparation}

Meconium samples collected from the infants born to the women with different levels of tobacco exposure were analyzed. A total of 52 women participated in the study consisting in taking meconium from their infants, 34 of them consented to saliva sampling. The samples were collected from the women aged between 25 and 40 years. The women were divided into 3 groups - women nonsmokers, not exposed to harmful substances present in tobacco during pregnancy, women exposed to tobacco components and active women smokers during pregnancy.

Table 1 contains information about the number of women belonging to the different groups.

The meconium and maternal saliva samples were collected into sterile glass vials from the newborns and their mothers at the Gynecology and Obstetrics Department 
Table 1. Information about the number of women in groups of the different donors

\begin{tabular}{lc}
\hline Collected material / Exposure & $\begin{array}{c}\text { Women } \\
(\mathrm{N}=52) \\
{[\mathrm{n}]}\end{array}$ \\
\hline Meconium & \\
non-smokers & 18 \\
passive smokers & 16 \\
active smokers & 18 \\
Saliva & \\
non-smokers & 14 \\
passive smokers & 10 \\
active smokers & 10 \\
\hline
\end{tabular}

of the Medical University of Gdańsk. Next, the samples were transported to the laboratory at the Department of Analytical Chemistry in Gdańsk University of Technology, Chemical Faculty and analyzed quantitatively and qualitatively for the presence of selected ions, including thiocyanate ion, as biomarkers of tobacco smoke exposure.

In order to assess the level of exposure of an infant delivered by the woman exposed to tobacco smoke, the samples of maternal saliva were also analyzed. This allowed to compare concentration levels of the tobacco biomarker, namely thiocyanate ion, in the biological samples collected from the mothers and their offspring. The saliva samples were collected in the morning, before teeth brushing. The women who consented to meconium sampling from their infants were asked to fill in a questionnaire in order to assess their exposure level to tobacco smoke components as well as dietary habits, which could be an additional source of indicator ions.

Information on the habits of the women included in the questionnaire allowed to divide the donors into the following groups: active smokers, non-smokers but exposed to components of ETS (passive smokers) and a group of non-smokers. A flow diagram of the analytical procedure is shown in Figure 1. The conducted

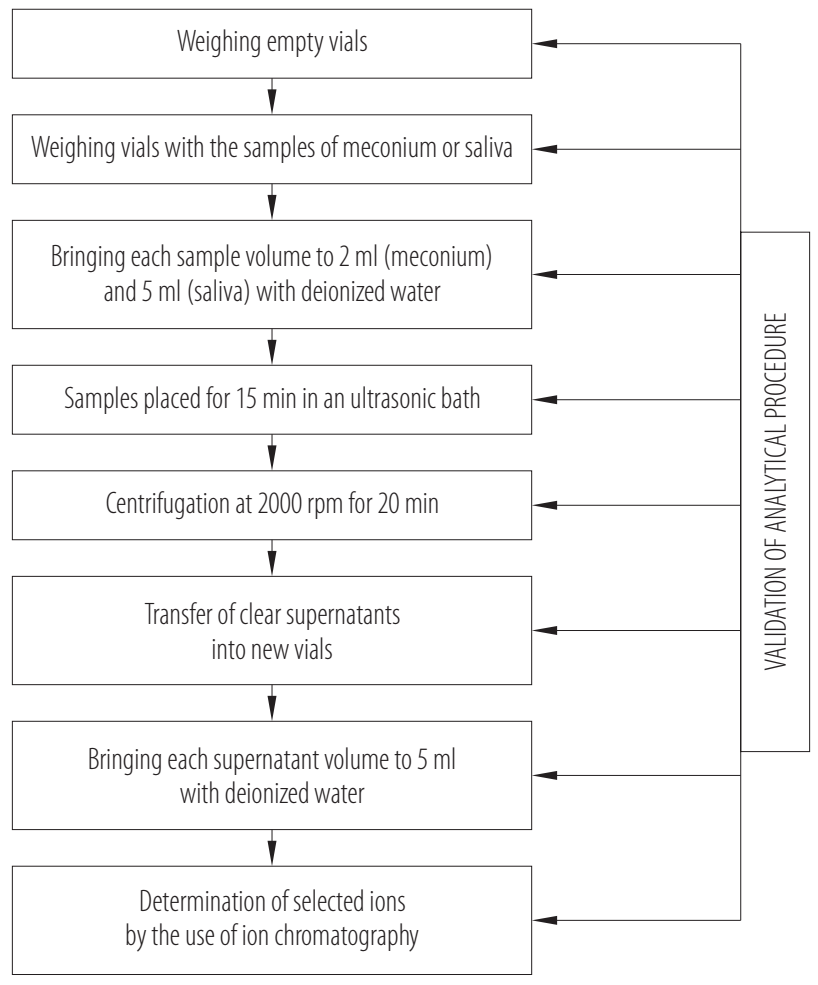

Fig. 1. Analytical procedure for processing the meconium and saliva samples in order to determine selected indicator ions by the use of ion chromatography

research was based on biological material of human origin therefore, it required a permission of Bioethics Committee. Such a permission was obtained on October 7, 2010 (No. NKEBN/80/2010).

\section{Chromatographic conditions}

The properly processed samples of meconium and saliva were analyzed by means of the Dionex ICS-3000 ion chromatographer. Table 2 contains information on analytical conditions and validation parameters values for the elaborated analytical procedure.

The elaborated methodology makes it possible to determine various ions (including thiocyanate ion) in the samples containing complex matrix, such as meconium. Thiocyanate ion is visibly separated from other ions, which facilitates its identification. An example chromatogram, obtained from the properly processed 
Table 2. Separation conditions for the analytes present in meconium samples, and validation parameter values for the analytical methodology

\begin{tabular}{|c|c|c|c|c|c|c|c|}
\hline Column & Suppressor & Eluent & Analyte & $\begin{array}{c}\text { LOD } \\
{[\mathrm{mg} / \mathrm{ml}]}\end{array}$ & $\begin{array}{c}\text { Precision } \\
{[\%]}\end{array}$ & $\begin{array}{c}\text { Linearity } \\
\text { (correlation } \\
\text { coefficient } \\
\mathrm{R}^{2} \text { ) }\end{array}$ & $\begin{array}{c}\text { Expanded } \\
\text { uncertainty } \\
{[\%]}\end{array}$ \\
\hline \multirow{8}{*}{$\begin{array}{l}\text { Ion Pac AS22 } \\
\text { Analytical } 2 \times 250 \mathrm{~mm}\end{array}$} & \multirow[t]{8}{*}{ ASRS-300 2-mm } & \multirow{8}{*}{$\begin{array}{l}4.5 \mathrm{mM} \mathrm{CO}_{3}^{2-} \\
1.4 \mathrm{mM} \mathrm{HCO}_{3}^{-}\end{array}$} & anions & & & & \\
\hline & & & $\mathrm{SCN}^{-}$ & 0.0008 & 1.07 & 0.998 & 10 \\
\hline & & & $\mathrm{F}^{-}$ & 0.0001 & 1.11 & 0.999 & 10 \\
\hline & & & $\mathrm{Cl}^{-}$ & 0.0002 & 0.80 & $>0.999$ & 10 \\
\hline & & & $\mathrm{NO}_{2}^{-}$ & 0.0001 & 1.72 & 0.988 & 10 \\
\hline & & & $\mathrm{NO}_{3}^{-}$ & 0.0001 & 0.92 & 0.997 & 10 \\
\hline & & & $\mathrm{PO}_{4}^{3-}$ & 0.0028 & 1.44 & 0.990 & 10 \\
\hline & & & $\mathrm{SO}_{4}^{2-}$ & 0.0001 & 0.79 & $>0.999$ & 10 \\
\hline \multirow{5}{*}{$\begin{array}{l}\text { Ion Pac CS16 } \\
\text { Analytical } 3 \times 250 \mathrm{~mm}\end{array}$} & \multirow[t]{5}{*}{ CSRS-300 2-mm } & \multirow[t]{5}{*}{$30 \mathrm{mM} \mathrm{CH}_{3} \mathrm{SO}_{3} \mathrm{H}$} & cations & & & & \\
\hline & & & $\mathrm{Na}^{+}$ & 0.0511 & 0.95 & $>0.999$ & 10 \\
\hline & & & $\mathrm{NH}_{4}^{+}$ & 0.1034 & 1.12 & 0.987 & 10 \\
\hline & & & $\mathrm{K}^{+}$ & 0.0168 & 0.98 & $>0.999$ & 10 \\
\hline & & & $\mathrm{Ca}^{2+}$ & 0.0188 & 0.98 & 0.990 & 10 \\
\hline
\end{tabular}

LOD - limit of detection; $\mathrm{R}^{2}$ - regression coeficient.

meconium sample (thiocyanate peak is marked), is presented in Figure 2.

\section{Pearson's correlation coeficient}

Pearson's correlation coefficient makes it possible to estimate the strength of a linear relationship between 2 variables. In this particular case, the variables are concentrations of specific ions. Based on the value of a correlation coefficient, the relationship between specific ions in the samples can be assessed. A linear relationship is one where an increasing or decreasing variable will cause a corresponding increase or decrease in another variable. The value of Pearson's coefficient is significant when it exceeds 0.5 . The higher the coefficient values, the stronger the correlation between the 2 variables. The calculations were performed by the use of the Statistica software package.

\section{Statisctical F-Snedecor and Student's t-test application}

In order to compare the results obtained in the analysis of samples collected from the offspring of the women belonging to different groups of donors, 2 tests were carried out - the F-Snedecor test, to compare the standard deviations and the Student's t-test - to compare the mean values and standard deviations. The Student's t-test was used to compare the results obtained in the analysis of the samples collected from the 2 different groups of donors. If the calculated $t$ value is greater than the value of $t_{k r}$, then the 2 groups differ significantly. If the computed value of the parameter $t$ is less than the $t_{k r}$, the 2 groups do not differ significantly.

If the $\mathrm{F}$ value calculated for a given group of samples is greater than the value of the $\mathrm{F}_{\mathrm{kr}}$, the results from the analysis of the samples collected from the groups differ significantly in terms of standard deviations. If the calculated 

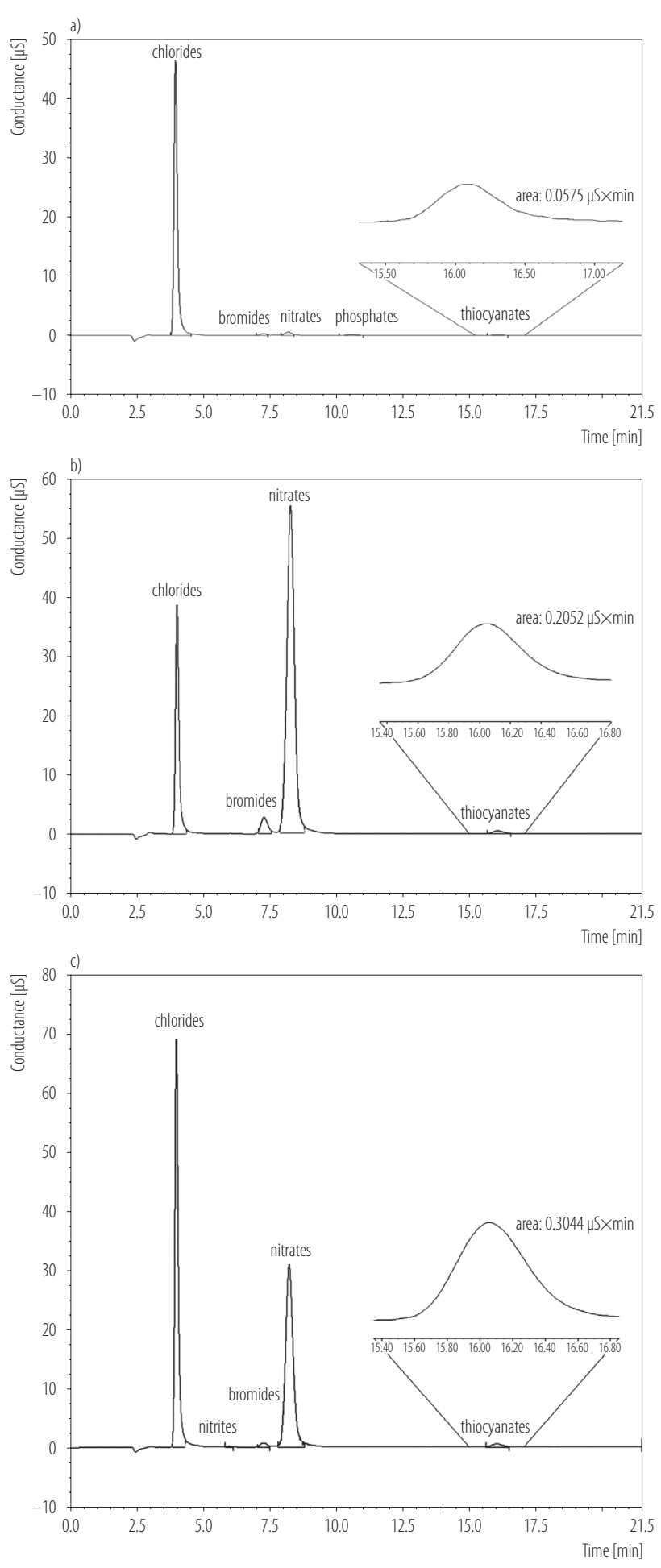

Fig. 2. Chromatograms obtained during the analysis of nasal discharge samples from the subjects variously exposed to environmental tobacco smoke (ETS) constituents: a) non-smokers, b) passive smokers, c) active smokers
F value is less than the $\mathrm{F}_{\mathrm{kr}}$, the 2 groups do not differ significantly in terms of standard deviations.

\section{RESULTS AND DISCUSSION}

\section{Concentrations of selected ions measured}

\section{in the meconium and maternal saliva samples}

from the women with different levels of exposure

\section{to tobacco smoke components}

In this study the results of thiocyanate ion determination in the meconium and saliva samples from the mothers with different levels of exposure to tobacco smoke and ETS constituents during pregnancy are presented. Some samples were collected from the newborn infants of the mothers who were not exposed to tobacco smoke during pregnancy (18 meconium samples). The level of thiocyanate ions, which is a well-known biomarker of tobacco smoke and ETS components was higher in the samples collected from the newborns whose mothers were smoking during pregnancy or were exposed to ETS constituents.

In literature there is no data about determination of thiocyanate ions in meconium samples. In this type of samples only determination of nicotine and its metabolites (like nicotine, cotinine, caffeine) has been carried out $[17,24,25]$. The present study is the 1 st study on the possibility of using a biomarker - thiocyanate ions, in the assessment of exposure of newborns whose mothers were active smokers or passive smokers.

Thiocyanate ion concentration, used as a biomarker of tobacco smoke exposure, was the highest in the meconium samples of the newborns whose mothers were smoking during pregnancy, and who were exposed to tobacco smoke constituents. The mean thiocyanate ion concentration in the smoking women was higher as compared to the passive female smokers, and higher than in the women who did not smoke and were not exposed to passive smoking. Data on the range of concentration values of specific ions measured in the meconium samples are presented in Table 3, and in the saliva samples in Table 4. Information on the concentration levels 
Table 3. Concentration values range for the determined analytes (cations and anions including thiocyanate ion) in the meconium samples from newborns collected from the mothers with different levels of environmental tobacco smoke (ETS) exposure

\begin{tabular}{|c|c|c|c|c|}
\hline \multirow[t]{2}{*}{ Analyte } & \multirow[t]{2}{*}{$\begin{array}{l}\text { LOD } \\
{[\mathrm{mg} / \mathrm{ml}]}\end{array}$} & \multicolumn{3}{|c|}{$\begin{array}{l}\text { Concentrations of analytes in the meconium } \\
\text { (range }(\mathrm{M})) \\
{[\mathrm{mg} / \mathrm{g}]}\end{array}$} \\
\hline & & pregnant smokers & pregnant passive smokers & pregnant non-smokers \\
\hline $\mathrm{SCN}^{-}$ & 0.0008 & $0.0130-10.1400(2.3900)$ & < LOD-4.9100 (1.0500) & $<$ LOD-3.5300 (0.8700) \\
\hline $\mathrm{F}^{-}$ & 0.0001 & $<$ LOD-0.0670 (0.0140) & < LOD-0.1860 (0.0140) & $<$ LOD-0.0250 (0.0040) \\
\hline $\mathrm{Cl}^{-}$ & 0.0002 & $0.0430-0.1680(0.1080)$ & $0.0020-0.4050(0.1120)$ & $0.0020-0.7320(0.1170)$ \\
\hline $\mathrm{NO}_{2}^{-}$ & 0.0001 & $<$ LOD-0.0216 (0.0044) & $<$ LOD $-0.0028(0.0002)$ & $<$ LOD-0.0855 (0.0033) \\
\hline $\mathrm{NO}_{3}^{-}$ & 0.0001 & $<$ LOD-0.0003 (0.0001) & $<$ LOD-0.0230 (0.0035) & $<$ LOD-0.0375 (0.0027) \\
\hline $\mathrm{PO}_{4}^{3-}$ & 0.0020 & $<$ LOD-0.3280 (0.2070) & $<$ LOD-0.4200 (0.0601) & $<$ LOD-0.7160 (0.0560) \\
\hline $\mathrm{SO}_{4}^{2-}$ & 0.0001 & $<$ LOD-0.9020 (0.2070) & < LOD-1.1950 (0.1730) & < LOD-1.1030 (0.1200) \\
\hline $\mathrm{Na}^{+}$ & 0.0020 & $0.2210-1.5670(0.7180)$ & $0.0510-1.4300(0.6330)$ & $0.0680-5.8600(1.0840)$ \\
\hline $\mathrm{NH}_{4}^{+}$ & 0.0020 & $0.5100-6.0900(1.9300)$ & $0.3000-2.4200(1.3200)$ & $0.3500-5.0900(1.4200)$ \\
\hline $\mathrm{K}^{+}$ & 0.0020 & $0.0590-0.3900(0.2050)$ & $0.0540-1.4700(0.5300)$ & $0.0170-4.8100(0.9800)$ \\
\hline $\mathrm{Ca}^{2+}$ & 0.0020 & $0.0440-0.2390(0.1020)$ & $0.0360-0.6800(0.1720)$ & $<$ LOD-0.4290 (0.1830) \\
\hline
\end{tabular}

LOD - limit of detection; ETS - environmental tobacco smoke; M - mean.

Table 4. Concentration values range for the determined analytes (cations and anions including thiocyanate ion) in the saliva samples collected from the mothers with different levels of environmental tobacco smoke (ETS) exposure

\begin{tabular}{lccc}
\hline & \multicolumn{3}{c}{$\begin{array}{c}\text { Concentrations of analytes in the saliva } \\
\text { Analyge }(\mathrm{M})) \\
{[\mathrm{mg} / \mathrm{g}]}\end{array}$} \\
\cline { 2 - 4 } & pregnant smokers & pregnant passive smokers & pregnant non-smokers \\
\hline $\mathrm{SCN}^{-}$ & $0.1700-2.6300(1.4300)$ & $0.1700-1.5800(0.6100)$ & $<$ LOD-2.7600 $(0.5400)$ \\
$\mathrm{F}^{-}$ & $<$LOD-0.0032 $(0.0017)$ & $<$ LOD-0.0039 $(0.0014)$ & $<$ LOD-0.0172 $(0.0017)$ \\
$\mathrm{Cl}^{-}$ & $0.4400-1.1500(0.7200)$ & $0.4600-1.6300(0.7900)$ & $0.0700-1.4800(0.7800)$ \\
$\mathrm{NO}_{2}{ }^{-}$ & $<$LOD & $<$LOD & $<$LOD \\
$\mathrm{NO}_{3}^{-}$ & $<$LOD-0.0140 $(0.0080)$ & $<$ LOD-0.1030 $(0.0220)$ & $<$ LOD-0.07700 $(0.01700)$ \\
$\mathrm{PO}_{4}^{3-}$ & $0.1200-0.4000(0.2300)$ & $0.0600-0.5100(0.2700)$ & $<$ LOD-0.6700 $(0.2300)$ \\
$\mathrm{SO}_{4}^{2-}$ & $0.0120-0.0940(0.0620)$ & $0.0030-0.3450(0.0510)$ & $<$ LOD-0.2160 $(0.0530)$ \\
$\mathrm{Na}^{+}$ & $0.7600-2.5900(1.4300)$ & $0.1800-2.0800(0.9000)$ & $0.1500-4.0100(0.9700)$ \\
$\mathrm{NH}_{4}^{+}$ & $0.3300-1.1300(0.6700)$ & $<$ LOD-1.4500 $(0.6100)$ & $<$ LOD-1.7900 $(0.5000)$ \\
$\mathrm{K}^{+}$ & $0.4300-1.8000(0.9800)$ & $<$ LOD-1.5500 $(0.8700)$ & $<$ LOD-2.5900 $(0.9100)$ \\
$\mathrm{Ca}^{2+}$ & $<$ LOD & $<$ LOD-0.1200 $(0.0900)$ & $<$ LOD-0.3300 $(0.1100)$ \\
\hline
\end{tabular}

Abbreviations as in Table 2 and 3. 

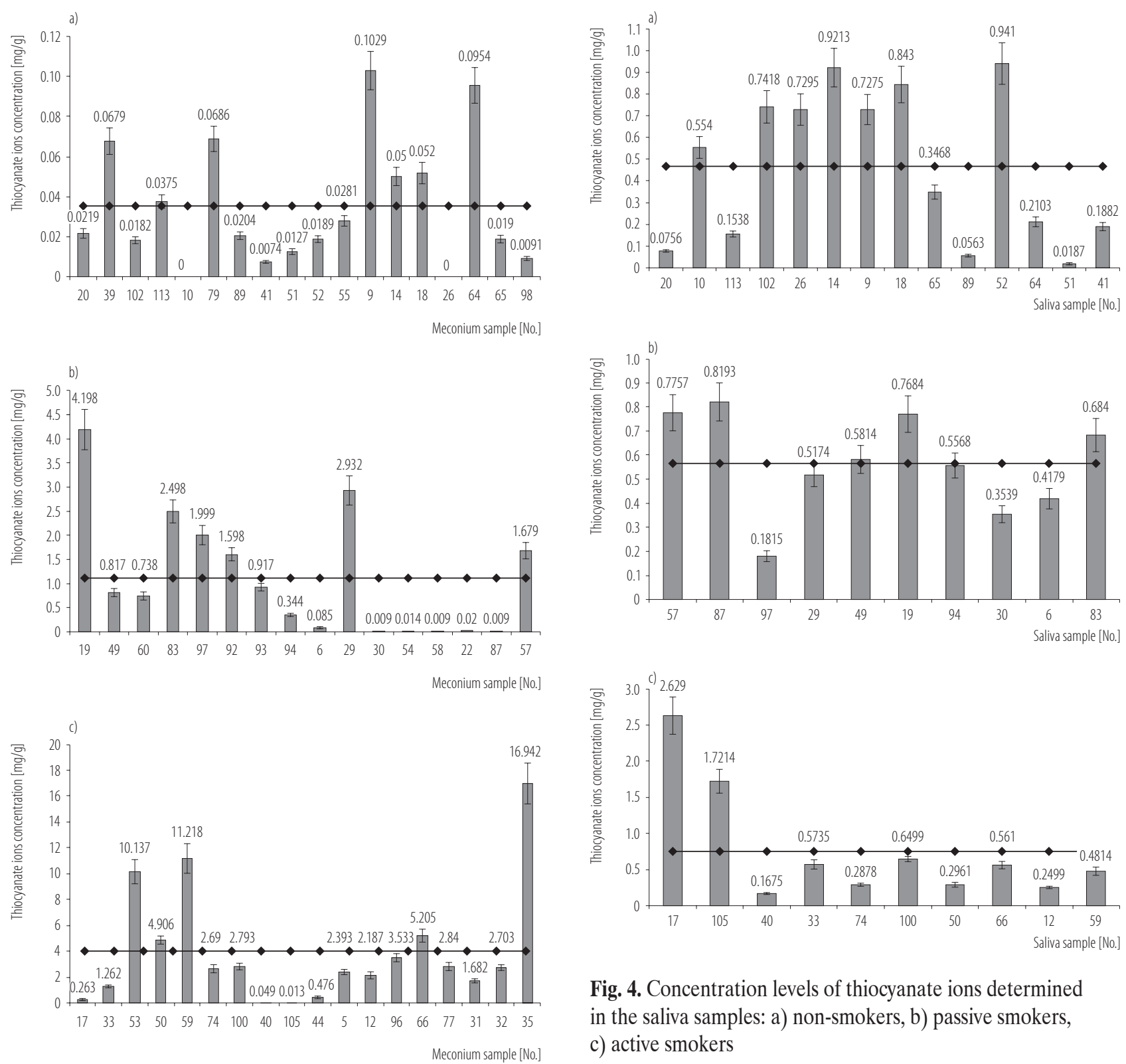

Fig. 4. Concentration levels of thiocyanate ions determined in the saliva samples: a) non-smokers, b) passive smokers, c) active smokers

Fig. 3. Concentration levels of thiocyanate ions determined in the meconium samples: a) non-smokers, b) passive smokers, c) active smokers

of thiocyanate ions determined in the meconium and saliva samples is shown in Figure 3 and 4.

Based on the obtained results, the highest mean thiocyanate ion concentrations were observed in the women who were active smokers. The mean concentration of this ion in the smoking women was over 2 times higher as

compared to the one reported in the passive smokers and non-smokers (Table 3 and 4).

The results of other studies conducted by our scientific center show that thiocyanate ions concentration determined in the samples of placenta and breast milk range from the limit of detection (LOD) $-0.5696 \mathrm{mg} / \mathrm{g}$ and < LOD-0.1101 mg/g, respectively.

Results of ion chromatography analysis of the meconium and maternal saliva samples for the presence of 
Table 5. Concentration levels of specific ions in the sample donor groups as compared to the control group

\begin{tabular}{|c|c|c|c|c|}
\hline \multirow{2}{*}{ Analyte } & \multicolumn{2}{|c|}{ Meconium } & \multicolumn{2}{|c|}{ Saliva } \\
\hline & smokers & passive smokers & smokers & passive smokers \\
\hline $\mathrm{SCN}^{-}$ & ++ & + & + & + \\
\hline $\mathrm{F}^{-}$ & 0 & 0 & 0 & 0 \\
\hline $\mathrm{Cl}^{-}$ & + & 0 & 0 & 0 \\
\hline $\mathrm{NO}_{3}^{-}$ & 0 & 0 & 0 & 0 \\
\hline $\mathrm{PO}_{4}^{3-}$ & + & + & - & - \\
\hline $\mathrm{SO}_{4}^{2-}$ & - & -- & 0 & 0 \\
\hline $\mathrm{Na}^{+}$ & + & - & + & + \\
\hline $\mathrm{NH}_{4}^{+}$ & + & - & - & - \\
\hline $\mathrm{K}^{+}$ & + & 0 & - & - \\
\hline
\end{tabular}

" $++"$ - a significantly higher concentration as compared to the non-smokers group.

"+" - higher concentration as compared to the non-smokers group.

"- -" - a significantly lower concentration as compared to the non-smokers group.

"-" - lower concentration as compared to the non-smokers group.

0 - no significant change in concentration as compared to the control group.

cations and anions (including thiocyanate ion) indicate that the concentration level of specific ions depends on the intensity of exposure to tobacco smoke and ETS constituents of the pregnant women. The concentrations of $\mathrm{SCN}^{-}, \mathrm{Cl}^{-}, \mathrm{PO}_{4}^{3-}, \mathrm{Na}^{+}, \mathrm{NH}_{4}^{+}$and $\mathrm{K}^{+}$ions in the meconium samples collected from the infants of the smoking mothers and passive smokers were higher than those from the newborns of the non-smoking and not exposed to ETS women. In the case of $\mathrm{SO}_{4}^{2-}$ ions, a concentration decrease was observed (Table 5). The results of ion determination in the properly processed samples of maternal saliva showed that the concentrations of $\mathrm{SCN}^{-}$and $\mathrm{Na}^{+}$ ions were higher in the smoking mothers and passive smokers as compared to the non-smoking and not exposed to ETS women (Table 5).

\section{Relationships between the concentrations of specific ions measured in the analyzed meconium and maternal saliva samples (Pearson's correlation coefficients)}

The obtained values of Pearson's correlation coefficient indicate that the strongest correlations were present between ions in the meconium samples collected from the infants whose mothers smoked during pregnancy. The coefficient values were the highest in the case of $\mathrm{SCN}^{-}$ and: $\mathrm{Cl}^{-}, \mathrm{Na}^{+}, \mathrm{NH}_{4}^{+}, \mathrm{K}^{+}$. This means that as the concentration of thiocyanate ion increases so do the concentrations of the other aforementioned ions. In the group of infants whose mothers were passive smokers or did not smoke during pregnancy, the following correlations, as based on Pearson's correlation coefficient values, were observed between $\mathrm{NO}_{2}^{-}$ and $\mathrm{Cl}^{-}, \mathrm{NH}_{4}^{+}$and $\mathrm{Br}^{-}, \mathrm{SO}_{4}^{2-}$ and $\mathrm{NH}_{4}^{+}$(Table 6-8).

The calculated values of the Pearson's correlation coefficient for the concentrations of specific ions in the maternal saliva samples indicate that the strongest correlations exist between the concentrations of $\mathrm{SCN}^{-}$and $\mathrm{F}^{-}, \mathrm{SO}_{4}^{2-}$ and $\mathrm{F}^{-}, \mathrm{NO}_{3}^{-}$and $\mathrm{PO}_{4}^{3-}$ in the samples from the women who smoked during pregnancy. In the passive female smoker group the highest correlation was between the concentrations of $\mathrm{Br}^{-}$and $\mathrm{Na}^{+}, \mathrm{SO}_{4}{ }^{2-}$ and $\mathrm{Cl}^{-}, \mathrm{NO}_{2}^{-}$and $\mathrm{K}^{+}$. The $\mathrm{SCN}^{-}$ was correlated with $\mathrm{NH}_{4}{ }^{+}$ions. In the non-smokers group there was no correlation between the ions concentrations (Table 9-11) - ions concentration was not correlated with 
Table 6. Pearson's correlation coefficient values calculated for the concentrations of ions in the meconium samples of the active smokers

\begin{tabular}{|c|c|c|c|c|c|c|c|c|c|c|c|}
\hline \multirow{2}{*}{ Variable } & \multicolumn{11}{|c|}{ Pearson's correlations } \\
\hline & $\mathrm{F}^{-}$ & $\mathrm{Cl}^{-}$ & $\mathrm{NO}_{2}^{-}$ & $\mathrm{Br}^{-}$ & $\mathrm{NO}_{3}^{-}$ & $\mathrm{PO}_{4}^{3-}$ & $\mathrm{SO}_{4}^{2-}$ & $\mathrm{SCN}^{-}$ & $\mathrm{Na}^{+}$ & $\mathrm{NH}_{4}^{+}$ & $\mathrm{K}^{+}$ \\
\hline $\mathrm{F}^{-}$ & 1.000 & & & & & & & & & & \\
\hline $\mathrm{Cl}^{-}$ & 0.059 & 1.000 & & & & & & & & & \\
\hline $\mathrm{NO}_{2}^{-}$ & -0.089 & 0.003 & 1.000 & & & & & & & & \\
\hline $\mathrm{Br}^{-}$ & 0.882 & 0.062 & -0.120 & 1.000 & & & & & & & \\
\hline $\mathrm{NO}_{3}^{-}$ & -0.165 & -0.091 & -0.055 & -0.009 & 1.000 & & & & & & \\
\hline $\mathrm{PO}_{4}^{3-}$ & 0.153 & 0.003 & -0.082 & 0.090 & -0.065 & 1.000 & & & & & \\
\hline $\mathrm{SO}_{4}^{2-}$ & -0.114 & -0.094 & -0.001 & -0.146 & 0.260 & -0.199 & 1.000 & & & & \\
\hline $\mathrm{SCN}^{-}$ & 0.326 & 0.739 & -0.129 & 0.383 & 0.176 & 0.317 & -0.310 & 1.000 & & & \\
\hline $\mathrm{Na}^{+}$ & -0.054 & 0.921 & -0.156 & 0.056 & 0.166 & 0.254 & -0.073 & 0.757 & 1.000 & & \\
\hline $\mathrm{NH}_{4}^{+}$ & 0.679 & 0.667 & -0.126 & 0.664 & 0.059 & 0.341 & -0.019 & 0.776 & 0.638 & 1.000 & \\
\hline $\mathrm{K}^{+}$ & -0.111 & 0.482 & -0.140 & 0.098 & 0.731 & 0.088 & -0.081 & 0.586 & 0.726 & 0.401 & 1.000 \\
\hline
\end{tabular}

Table 7. Pearson's correlation coefficient values calculated for the concentrations of ions in the meconium samples of the passive smokers

\begin{tabular}{|c|c|c|c|c|c|c|c|c|c|c|c|}
\hline \multirow{2}{*}{ Variable } & \multicolumn{11}{|c|}{ Pearson's correlations } \\
\hline & $\mathrm{F}^{-}$ & $\mathrm{Cl}^{-}$ & $\mathrm{NO}_{2}^{-}$ & $\mathrm{Br}^{-}$ & $\mathrm{NO}_{3}^{-}$ & $\mathrm{PO}_{4}^{3-}$ & $\mathrm{SO}_{4}^{2-}$ & $\mathrm{SCN}^{-}$ & $\mathrm{Na}^{+}$ & $\mathrm{NH}_{4}^{+}$ & $\mathrm{K}^{+}$ \\
\hline $\mathrm{F}^{-}$ & 1.000 & & & & & & & & & & \\
\hline $\mathrm{Cl}^{-}$ & 0.125 & 1.000 & & & & & & & & & \\
\hline $\mathrm{NO}_{2}^{-}$ & -0.119 & 0.828 & 1.000 & & & & & & & & \\
\hline $\mathrm{Br}^{-}$ & -0.111 & 0.165 & -0.135 & 1.000 & & & & & & & \\
\hline $\mathrm{NO}_{3}^{-}$ & 0.249 & 0.138 & -0.131 & -0.240 & 1.000 & & & & & & \\
\hline $\mathrm{PO}_{4}^{3-}$ & -0.042 & -0.061 & -0.111 & 0.064 & 0.404 & 1.000 & & & & & \\
\hline $\mathrm{SO}_{4}^{2-}$ & -0.118 & 0.073 & -0.116 & 0.486 & -0.063 & 0.145 & 1.000 & & & & \\
\hline $\mathrm{SCN}^{-}$ & -0.329 & 0.014 & -0.044 & 0.355 & -0.334 & -0.317 & -0.279 & 1.000 & & & \\
\hline $\mathrm{Na}^{+}$ & 0.295 & 0.198 & -0.232 & 0.525 & 0.177 & -0.008 & 0.537 & 0.058 & 1.000 & & \\
\hline $\mathrm{NH}_{4}^{+}$ & -0.050 & 0.244 & -0.069 & 0.687 & 0.045 & 0.214 & 0.895 & -0.161 & 0.627 & 1.000 & \\
\hline $\mathrm{K}^{+}$ & 0.078 & 0.379 & 0.216 & -0.080 & 0.524 & 0.685 & -0.057 & -0.207 & 0.095 & 0.153 & 1.000 \\
\hline
\end{tabular}

Table 8. Pearson's correlation coefficient values calculated for the concentrations of ions in the meconium samples of the non-smokers

\begin{tabular}{|c|c|c|c|c|c|c|c|c|c|c|c|}
\hline \multirow{2}{*}{ Variable } & \multicolumn{11}{|c|}{ Pearson's correlations } \\
\hline & $\mathrm{F}^{-}$ & $\mathrm{Cl}^{-}$ & $\mathrm{NO}_{2}^{-}$ & $\mathrm{Br}^{-}$ & $\mathrm{NO}_{3}^{-}$ & $\mathrm{PO}_{4}^{3-}$ & $\mathrm{SO}_{4}^{2-}$ & $\mathrm{SCN}^{-}$ & $\mathrm{Na}^{+}$ & $\mathrm{NH}_{4}^{+}$ & $\mathrm{K}^{+}$ \\
\hline$\overline{\mathrm{F}^{-}}$ & 1.000 & & & & & & & & & & \\
\hline $\mathrm{Cl}^{-}$ & 0.542 & 1.000 & & & & & & & & & \\
\hline $\mathrm{NO}_{2}^{-}$ & -0.111 & -0.255 & 1.000 & & & & & & & & \\
\hline
\end{tabular}


Table 8. Pearson's correlation coefficient values calculated for the concentrations of ions in the meconium samples of the non-smokers - cont.

\begin{tabular}{|c|c|c|c|c|c|c|c|c|c|c|c|}
\hline \multirow{2}{*}{ Variable } & \multicolumn{11}{|c|}{ Pearson's correlations } \\
\hline & $\mathrm{F}^{-}$ & $\mathrm{Cl}^{-}$ & $\mathrm{NO}_{2}^{-}$ & $\mathrm{Br}^{-}$ & $\mathrm{NO}_{3}^{-}$ & $\mathrm{PO}_{4}^{3-}$ & $\mathrm{SO}_{4}^{2-}$ & $\mathrm{SCN}^{-}$ & $\mathrm{Na}^{+}$ & $\mathrm{NH}_{4}^{+}$ & $\mathrm{K}^{+}$ \\
\hline $\mathrm{Br}^{-}$ & 0.383 & 0.306 & -0.065 & 1.000 & & & & & & & \\
\hline $\mathrm{NO}_{3}^{-}$ & -0.069 & -0.213 & -0.085 & -0.232 & 1.000 & & & & & & \\
\hline $\mathrm{PO}_{4}^{3-}$ & -0.111 & 0.165 & 0.629 & -0.078 & -0.171 & 1.000 & & & & & \\
\hline $\mathrm{SO}_{4}^{2-}$ & -0.192 & 0.275 & -0.325 & 0.019 & 0.237 & -0.267 & 1.000 & & & & \\
\hline $\mathrm{SCN}^{-}$ & 0.230 & 0.543 & -0.289 & -0.145 & 0.237 & -0.204 & 0.311 & 1.000 & & & \\
\hline $\mathrm{Na}^{+}$ & 0.396 & 0.736 & -0.046 & 0.426 & -0.427 & 0.246 & 0.370 & 0.181 & 1.000 & & \\
\hline $\mathrm{NH}_{4}^{+}$ & 0.354 & 0.846 & -0.146 & 0.255 & -0.295 & 0.169 & 0.414 & 0.434 & 0.841 & 1.000 & \\
\hline $\mathrm{K}^{+}$ & 0.026 & 0.118 & 0.338 & 0.028 & -0.242 & 0.336 & 0.361 & -0.161 & 0.374 & 0.438 & 1.000 \\
\hline
\end{tabular}

Table 9. Pearson's correlation coefficient values calculated for the concentrations of ions in the saliva samples of the active smokers

\begin{tabular}{|c|c|c|c|c|c|c|c|c|c|c|c|}
\hline \multirow{2}{*}{ Variable } & \multicolumn{11}{|c|}{ Pearson's correlations } \\
\hline & $\mathrm{F}^{-}$ & $\mathrm{Cl}^{-}$ & $\mathrm{NO}_{2}^{-}$ & $\mathrm{Br}^{-}$ & $\mathrm{NO}_{3}^{-}$ & $\mathrm{PO}_{4}^{3-}$ & $\mathrm{SO}_{4}^{2-}$ & $\mathrm{SCN}^{-}$ & $\mathrm{Na}^{+}$ & $\mathrm{NH}_{4}^{+}$ & $\mathrm{K}^{+}$ \\
\hline $\mathrm{F}^{-}$ & 1.000 & & & & & & & & & & \\
\hline $\mathrm{Cl}^{-}$ & -0.630 & 1.000 & & & & & & & & & \\
\hline $\mathrm{NO}_{2}^{-}$ & -0.292 & -0.045 & 1.000 & & & & & & & & \\
\hline $\mathrm{Br}^{-}$ & 0.397 & -0.493 & -0.176 & 1.000 & & & & & & & \\
\hline $\mathrm{NO}_{3}^{-}$ & -0.297 & 0.025 & 0.140 & -0.009 & 1.000 & & & & & & \\
\hline $\mathrm{PO}_{4}^{3-}$ & -0.404 & 0.136 & 0.200 & 0.090 & 0.749 & 1.000 & & & & & \\
\hline $\mathrm{SO}_{4}^{2-}$ & 0.835 & -0.639 & -0.127 & -0.146 & -0.392 & -0.268 & 1.000 & & & & \\
\hline $\mathrm{SCN}^{-}$ & -0.936 & 0.465 & -0.162 & 0.383 & 0.163 & 0.163 & -0.158 & 1.000 & & & \\
\hline $\mathrm{Na}^{+}$ & -0.140 & -0.033 & -0.050 & 0.056 & 0.520 & 0.729 & 0.167 & 0.309 & 1.000 & & \\
\hline $\mathrm{NH}_{4}^{+}$ & -0.515 & 0.003 & -0.229 & 0.664 & 0.246 & 0.466 & -0.308 & -0.154 & 0.522 & 1.000 & \\
\hline$\underline{\mathrm{K}^{+}}$ & -0.199 & 0.205 & -0.022 & 0.098 & 0.196 & 0.677 & 0.186 & 0.393 & 0.791 & 0.338 & 1.000 \\
\hline
\end{tabular}

Table 10. Pearson's correlation coefficient values calculated for the concentrations of ions in the saliva samples of the passive smokers

\begin{tabular}{|c|c|c|c|c|c|c|c|c|c|c|c|}
\hline \multirow{2}{*}{ Variable } & \multicolumn{11}{|c|}{ Pearson's correlations } \\
\hline & $\mathrm{F}^{-}$ & $\mathrm{Cl}^{-}$ & $\mathrm{NO}_{2}^{-}$ & $\mathrm{Br}^{-}$ & $\mathrm{NO}_{3}^{-}$ & $\mathrm{PO}_{4}^{3-}$ & $\mathrm{SO}_{4}^{2-}$ & $\mathrm{SCN}^{-}$ & $\mathrm{Na}^{+}$ & $\mathrm{NH}_{4}^{+}$ & $\mathrm{K}^{+}$ \\
\hline$\overline{\mathrm{F}^{-}}$ & 1.000 & & & & & & & & & & \\
\hline $\mathrm{Cl}^{-}$ & 0.226 & 1.000 & & & & & & & & & \\
\hline $\mathrm{NO}_{2}^{-}$ & -0.183 & 0.416 & 1.000 & & & & & & & & \\
\hline $\mathrm{Br}^{-}$ & 0.039 & -0.056 & 0.037 & 1.000 & & & & & & & \\
\hline $\mathrm{NO}_{3}^{-}$ & -0.239 & -0.242 & 0.635 & 0.110 & 1.000 & & & & & & \\
\hline
\end{tabular}


Table 10. Pearson's correlation coefficient values calculated for the concentrations of ions in the saliva samples of the passive smokers - cont.

\begin{tabular}{|c|c|c|c|c|c|c|c|c|c|c|c|}
\hline \multirow{2}{*}{ Variable } & \multicolumn{11}{|c|}{ Pearson's correlations } \\
\hline & $\mathrm{F}^{-}$ & $\mathrm{Cl}^{-}$ & $\mathrm{NO}_{2}^{-}$ & $\mathrm{Br}^{-}$ & $\mathrm{NO}_{3}^{-}$ & $\mathrm{PO}_{4}^{3-}$ & $\mathrm{SO}_{4}^{2-}$ & $\mathrm{SCN}^{-}$ & $\mathrm{Na}^{+}$ & $\mathrm{NH}_{4}^{+}$ & $\mathrm{K}^{+}$ \\
\hline $\mathrm{PO}_{4}^{3-}$ & -0.581 & 0.309 & 0.529 & 0.088 & 0.216 & 1.000 & & & & & \\
\hline $\mathrm{SO}_{4}^{2-}$ & -0.134 & 0.747 & 0.616 & 0.024 & 0.393 & 0.595 & 1.000 & & & & \\
\hline $\mathrm{SCN}^{-}$ & 0.467 & 0.112 & 0.074 & 0.491 & 0.393 & -0.251 & -0.278 & 1.000 & & & \\
\hline $\mathrm{Na}^{+}$ & 0.451 & 0.125 & 0.050 & 0.782 & -0.048 & -0.016 & 0.146 & 0.460 & 1.000 & & \\
\hline $\mathrm{NH}_{4}^{+}$ & -0.173 & -0.353 & 0.007 & 0.555 & 0.497 & -0.254 & -0.356 & 0.581 & 0.284 & 1.000 & \\
\hline $\mathrm{K}^{+}$ & -0.027 & 0.444 & 0.732 & -0.072 & 0.259 & 0.649 & 0.584 & -0.201 & 0.178 & -0.488 & 1.000 \\
\hline
\end{tabular}

Table 11. Pearson's correlation coefficient values calculated for the concentrations of ions in the saliva samples of the non-smokers

\begin{tabular}{|c|c|c|c|c|c|c|c|c|c|c|c|}
\hline \multirow{2}{*}{ Variable } & \multicolumn{11}{|c|}{ Pearson's correlations } \\
\hline & $\mathrm{F}^{-}$ & $\mathrm{Cl}^{-}$ & $\mathrm{NO}_{2}^{-}$ & $\mathrm{Br}^{-}$ & $\mathrm{NO}_{3}^{-}$ & $\mathrm{PO}_{4}^{3-}$ & $\mathrm{SO}_{4}^{2-}$ & $\mathrm{SCN}^{-}$ & $\mathrm{Na}^{+}$ & $\mathrm{NH}_{4}^{+}$ & $\mathrm{K}^{+}$ \\
\hline $\mathrm{F}^{-}$ & 1.000 & & & & & & & & & & \\
\hline $\mathrm{Cl}^{-}$ & 0.153 & 1.000 & & & & & & & & & \\
\hline $\mathrm{NO}_{2}^{-}$ & -0.076 & -0.102 & 1.000 & & & & & & & & \\
\hline $\mathrm{Br}^{-}$ & -0.012 & 0.344 & -0.222 & 1.000 & & & & & & & \\
\hline $\mathrm{NO}_{3}^{-}$ & -0.551 & -0.021 & -0.227 & 0.833 & 1.000 & & & & & & \\
\hline $\mathrm{PO}_{4}^{3-}$ & 0.049 & 0.459 & 0.052 & 0.764 & 0.474 & 1.000 & & & & & \\
\hline $\mathrm{SO}_{4}^{2-}$ & -0.044 & 0.536 & 0.197 & 0.541 & 0.036 & 0.772 & 1.000 & & & & \\
\hline $\mathrm{SCN}^{-}$ & -0.097 & 0.239 & 0.153 & 0.001 & 0.111 & -0.106 & -0.227 & 1.000 & & & \\
\hline $\mathrm{Na}^{+}$ & -0.010 & 0.291 & -0.212 & 0.894 & 0.715 & 0.867 & 0.736 & -0.197 & 1.000 & & \\
\hline $\mathrm{NH}_{4}^{+}$ & 0.359 & 0.238 & 0.120 & 0.210 & -0.070 & 0.164 & 0.600 & -0.075 & 0.200 & 1.000 & \\
\hline $\mathrm{K}^{+}$ & 0.116 & 0.477 & 0.015 & 0.687 & 0.336 & 0.961 & 0.870 & -0.209 & 0.852 & 0.290 & 1.000 \\
\hline
\end{tabular}

the concentration of tiocyanate ions. Most of correlations between the ions occurred in the non-smokers group, which means that ions interacted with one another.

\section{Statisctical F-Snedecor and Student's t-test}

The results of the calculations are presented in Table 12. Based on the F-Snedecor and Student's t-test, it was observed that concentrations of $\mathrm{SCN}^{-}$were statistically significantly different in the group of smokers - the active smoking person and non-smoking person, and in the group of the passive smokers and non-smoking women.

\section{CONCLUSIONS}

The conducted analyses confirm the hypothesis that thiocyanate ion is a suitable biomarker of tobacco smoke exposure. The highest concentration of this ion was measured in the meconium samples collected from the infants whose mothers were smoking during pregnancy and in the samples of saliva collected from the smoking women. In this particular case, the concentrations were 2 and 3 times higher than those determined in the samples collected from the mothers who were passive smokers or were not exposed to tobacco smoke at all. Moreover, 
Table 12. The calculated $\mathrm{F}_{\text {sample }}$ values and $\mathrm{t}_{\text {sample }}$ values determined in the meconium samples collected from the infants whose mothers were nonsmoking, passive and active smokers

\begin{tabular}{|c|c|c|c|c|c|c|}
\hline Analyte & $\begin{array}{l}\text { Calculated } \\
\mathrm{F}_{\text {sample }} \text { value }\end{array}$ & $\begin{array}{l}\text { Critical value } \\
\text { of } F\end{array}$ & $\begin{array}{l}\text { Verification } \\
\text { of the null } \\
\text { hypothesis } \\
\text { against the } \\
\text { alternative one }\end{array}$ & $\begin{array}{l}\text { Calculated } \\
\mathrm{t}_{\text {sample }} \text { value }\end{array}$ & $\begin{array}{l}\text { Critical value } \\
\text { of } t\end{array}$ & $\begin{array}{l}\text { Verification } \\
\text { of the null } \\
\text { hypothesis } \\
\text { against the } \\
\text { alternative one }\end{array}$ \\
\hline \multicolumn{7}{|c|}{$\begin{array}{l}\text { Non-smoking person and } \\
\text { passive smoking person }\end{array}$} \\
\hline $\mathrm{F}^{-}$ & 8.187 & 2.368 & $\mu_{1} \neq \mu_{2}$ & 0.210 & 2.037 & $\mu_{1}=\mu_{2}$ \\
\hline $\mathrm{Cl}^{-}$ & 0.901 & 2.368 & $\mu_{1}=\mu_{2}$ & 0.010 & 2.037 & $\mu_{1}=\mu_{2}$ \\
\hline $\mathrm{NO}_{2}^{-}$ & 0.000 & 2.368 & $\mu_{1}=\mu_{2}$ & 0.950 & 2.037 & $\mu_{1}=\mu_{2}$ \\
\hline $\mathrm{Br}^{-}$ & 0.025 & 2.368 & $\mu_{1}=\mu_{2}$ & 1.620 & 2.037 & $\mu_{1}=\mu_{2}$ \\
\hline $\mathrm{NO}_{3}^{-}$ & 1.448 & 2.368 & $\mu_{1}=\mu_{2}$ & 0.000 & 2.037 & $\mu_{1}=\mu_{2}$ \\
\hline $\mathrm{PO}_{4}^{3-}$ & 5.312 & 2.368 & $\mu_{1}=\mu_{2}$ & 1.060 & 2.037 & $\mu_{1}=\mu_{2}$ \\
\hline $\mathrm{SO}_{4}^{2-}$ & 6.192 & 2.368 & $\mu_{1} \neq \mu_{2}$ & 1.530 & 2.037 & $\mu_{1}=\mu_{2}$ \\
\hline $\mathrm{SCN}^{-}$ & 0.001 & 2.368 & $\mu_{1}=\mu_{2}$ & 3.650 & 2.037 & $\mu_{1} \neq \mu_{2}$ \\
\hline $\mathrm{Na}^{+}$ & 2.001 & 2.316 & $\mu_{1}=\mu_{2}$ & 2.001 & 2.316 & $\mu_{1}=\mu_{2}$ \\
\hline $\mathrm{NH}_{4}^{+}$ & 0.408 & 2.316 & $\mu_{1}=\mu_{2}$ & 0.408 & 2.316 & $\mu_{1}=\mu_{2}$ \\
\hline $\mathrm{K}^{+}$ & 1.386 & 2.316 & $\mu_{1}=\mu_{2}$ & 1.386 & 2.316 & $\mu_{1}=\mu_{2}$ \\
\hline \multicolumn{7}{|c|}{$\begin{array}{l}\text { Non-smoking person and } \\
\text { active smoking person }\end{array}$} \\
\hline $\mathrm{F}^{-}$ & 7.482 & 2.272 & $\mu_{1} \neq \mu_{2}$ & 0.810 & 2.032 & $\mu_{1}=\mu_{2}$ \\
\hline $\mathrm{Cl}^{-}$ & 0.658 & 2.272 & $\mu_{1}=\mu_{2}$ & 0.240 & 2.032 & $\mu_{1}=\mu_{2}$ \\
\hline $\mathrm{NO}_{2}^{-}$ & 0.005 & 2.272 & $\mu_{1}=\mu_{2}$ & 0.650 & 2.032 & $\mu_{1}=\mu_{2}$ \\
\hline $\mathrm{Br}^{-}$ & 0.041 & 2.272 & $\mu_{1}=\mu_{2}$ & 1.030 & 2.032 & $\mu_{1}=\mu_{2}$ \\
\hline $\mathrm{NO}_{3}^{-}$ & 30.720 & 2.272 & $\mu_{1}=\mu_{2}$ & 1.430 & 2.032 & $\mu_{1}=\mu_{2}$ \\
\hline $\mathrm{PO}_{4}^{3-}$ & 5.508 & 2.272 & $\mu_{1} \neq \mu_{2}$ & 0.900 & 2.032 & $\mu_{1}=\mu_{2}$ \\
\hline $\mathrm{SO}_{4}^{2-}$ & 1.684 & 2.272 & $\mu_{1} \neq \mu_{2}$ & 1.020 & 2.032 & $\mu_{1}=\mu_{2}$ \\
\hline $\mathrm{SCN}^{-}$ & 0.000 & 2.272 & $\mu_{1}=\mu_{2}$ & 3.710 & 2.032 & $\mu_{1} \neq \mu_{2}$ \\
\hline $\mathrm{Na}^{+}$ & 0.103 & 2.232 & $\mu_{1}=\mu_{2}$ & 0.103 & 2,232 & $\mu_{1}=\mu_{2}$ \\
\hline $\mathrm{NH}_{4}^{+}$ & 0.264 & 2.232 & $\mu_{1}=\mu_{2}$ & 0.264 & 2.232 & $\mu_{1}=\mu_{2}$ \\
\hline $\mathrm{K}^{+}$ & 0.093 & 2.232 & $\mu_{1}=\mu_{2}$ & 0.093 & 2.232 & $\mu_{1}=\mu_{2}$ \\
\hline \multicolumn{7}{|c|}{$\begin{array}{l}\text { Passive smoking person } \\
\text { and active smoking } \\
\text { person }\end{array}$} \\
\hline $\mathrm{F}^{-}$ & 0.914 & 2.307 & $\mu_{1}=\mu_{2}$ & 0.370 & 2.037 & $\mu_{1}=\mu_{2}$ \\
\hline $\mathrm{Cl}^{-}$ & 0.731 & 2.307 & $\mu_{1}=\mu_{2}$ & 1.960 & 2.037 & $\mu_{1}=\mu_{2}$ \\
\hline $\mathrm{NO}_{2}^{-}$ & 17.746 & 2.307 & $\mu_{1} \neq \mu_{2}$ & 0.730 & 2.037 & $\mu_{1}=\mu_{2}$ \\
\hline $\mathrm{Br}^{-}$ & 1.648 & 2.307 & $\mu_{1}=\mu_{2}$ & 1.530 & 2.037 & $\mu_{1}=\mu_{2}$ \\
\hline $\mathrm{NO}_{3}^{-}$ & 21.222 & 2.307 & $\mu_{1}=\mu_{2}$ & 0.000 & 2.037 & $\mu_{1}=\mu_{2}$ \\
\hline $\mathrm{PO}_{4}^{3-}$ & 1.037 & 2.307 & $\mu_{1} \neq \mu_{2}$ & 1.100 & 2.037 & $\mu_{1}=\mu_{2}$ \\
\hline
\end{tabular}


Table 12. The calculated $\mathrm{F}_{\text {sample }}$ values and $\mathrm{t}_{\text {sample }}$ values determined in the meconium samples collected from the infants whose mothers were nonsmoking, passive and active smokers - cont.

\begin{tabular}{lcccccc}
\hline \multicolumn{1}{c}{ Analyte } & $\begin{array}{c}\text { Calculated } \\
\mathrm{F}_{\text {sample }} \text { value }\end{array}$ & $\begin{array}{c}\text { Critical value } \\
\text { of } \mathrm{F}\end{array}$ & $\begin{array}{c}\text { Verification } \\
\text { of the null } \\
\text { hypothesis } \\
\text { against the } \\
\text { alternative one }\end{array}$ & $\begin{array}{c}\text { Calculated } \\
\mathrm{t}_{\text {sample }} \text { value }\end{array}$ & $\begin{array}{c}\text { Critical value } \\
\text { of } \mathrm{t}\end{array}$ & $\begin{array}{c}\text { Verification } \\
\text { of the null } \\
\text { hypothesis } \\
\text { against the } \\
\text { alternative one }\end{array}$ \\
\hline $\begin{array}{l}\text { Passive smoking person } \\
\text { and active smoking } \\
\text { person - cont. }\end{array}$ & & & & & \\
$\mathrm{SO}_{4}{ }^{-2}$ & 0.272 & 2.307 & $\mu_{1}=\mu_{2}$ & 1.600 & 2.037 & $\mu_{1}=\mu_{2}$ \\
$\mathrm{SCN}^{-}$ & 0.080 & 2.307 & $\mu_{1}=\mu_{2}$ & 3.420 & 2.037 & $\mu_{1} \neq \mu_{2}$ \\
$\mathrm{Na}^{+}$ & 0.051 & 2.249 & $\mu_{1}=\mu_{2}$ & 0.051 & 2.249 & $\mu_{1}=\mu_{2}$ \\
$\mathrm{NH}_{4}^{+}$ & 0.647 & 2.249 & $\mu_{1}=\mu_{2}$ & 0.647 & 2.249 & $\mu_{1}=\mu_{2}$ \\
$\mathrm{~K}^{+}$ & 0.067 & 2.249 & $\mu_{1}=\mu_{2}$ & 0.067 & 2.249 & $\mu_{1}=\mu_{2}$ \\
\hline
\end{tabular}

the obtained results indicate that the content of ions is connected with the level of tobacco smoke exposure. This means that ETS components influence chemical composition of biological materials such as saliva and meconium.

The study results described in this paper can constitute a basis for the following conclusions:

- saliva as well as meconium is a suitable biological material, which can be used for determination of biomarkers of ETS exposure,

- meconium collected from a newborn can be an indicator of fetal exposure to harmful tobacco smoke components during pregnancy,

- there are correlations between the concentrations of inorganic ions, which indicate the effects of exposure to tobacco smoke and of its content,

- ion chromatography is a suitable technique for thiocyanate ion determination in the samples of biological material.

\section{REFERENCES}

1. Narkowicz S, Płotka J, Polkowska Ż, Biziuk M, Namieśnik J. Prenatal exposure to substance of abuse: A worldwide problem. Environ Int. 2013;54:141-63, http://dx.doi.org/10.1016/ j.envint.2013.01.011.
2. Płotka J, Narkowicz S, Polkowska Ż, Biziuk M, Namieśnik J. Effects of addictive substances during pregnancy and infancy and their analysis in biological materials. Rev Environ Contam Toxicol. 2014;227:55-77, http://dx.doi.org/10.1007/978-3319-01327-5_2.

3. Narkowicz S, Polkowska Ż, Namieśnik J. Analysis of markers of exposure to constituents of environmental tobacco smoke (ETS). Crit Rev Anal Chem. 2012;42:16-37, http:// dx.doi.org/10.1080/10408347.2012.629948.

4. Borgerdinga M, Klusb H. Analysis of complex mixtures Cigarette smoke. Exp Toxicol Pathol. 2005;57:43-73, http:// dx.doi.org/10.1016/j.etp.2005.05.010.

5. Eskenazi B, Castorina R. Association of prenatal maternal or postnatal child environmental tobacco smoke exposure and neurodevelopmental and behavioral problems in children. Environ Health Perspect. 1999;107:991-1000, http://dx.doi. org/10.1289/ehp.99107991.

6. Gilmour MI, Jaakkola MS, London SL, Nel AE, Rogers CA. How exposure to environmental tobacco smoke, outdoor air pollutants, and increased pollen burdens influences the incidence of asthma. Environ Health Perspect. 2006;114:627-33, http://dx.doi.org/10.1289/ehp.8380.

7. Narkowicz S, Płotka J, Polkowska Ż, Biziuk M, Namieśnik J. Prenatal exposure to substances of abuse: A worldwide 
problem. Environ Int. 2013;54:141-63, http://dx.doi.org/ 10.1016/j.envint.2013.01.011.

8. California Environmental Protection Agency, Office of Environmental Health Hazard Assessment, Air Toxicology and Epidemiology Branch. Proposed identification of environmental tobacco smoke as a toxic air contaminant. Part B: Health effects. California Environmental Protection Agency, Office of Environmental Health Hazard Assessment, Air Toxicology and Epidemiology Branch; 2005 [cited 2014 Jun 5]. Available from: http://oehha.ca.gov/air/ environmental_tobacco/pdf/app3partb2005.pdf.

9. Air Resources Board. Proposed identification of environmental tobacco smoke as a toxic air contaminant. Part A Exposure assessment. California Environmental Protection Agency, Air Resources Board, Office of Environmental Health Hazard Assessment; 2005 [cited 2014 Jun 5]. Available from: http://oehha.ca.gov/air/environmental_tobacco/ pdf/app3parta2005.pdf.

10. Counts ME, Hsu FS, Laffoon SW, Dwyer RW, Cox RH. Mainstream smoke constituent yields and predicting relationships from a worldwide market sample of cigarette brands: ISO smoking conditions. Regul Toxicol Pharmacol. 2004; 39(2):111-34, http://dx.doi.org/10.1016/j.yrtph.2003.12.005.

11. Rummenie VT, Matsumoto Y, Dogru M, Wang Y, Hu Y, Ward SK, et al. Tear cytokine and ocular surface alterations following brief passive cigarette smoke exposure. Cytokine. 2008;43(2):200-8, http://dx.doi.org/10.1016/j.cy to.2008.05.011.

12. Satici A, Bitiren M, Ozardali I, Vural H, Kilic A, Guzey M. The effects of chronic smoking on the ocular surface and tear characteristics: A clinical, histological and biochemical study. Acta Ophthalmol Scand. 2003;81(6):583-90, http:// dx.doi.org/10.1111/j.1395-3907.2003.00158.x.

13. Baker RR. Smoke generation inside a burning cigarette: Modifying combustion to develop cigarettes that may be less hazardous to health. Prog Energy Combust Sci. 2006;32(4):373-85, http://dx.doi.org/10.1016/j.pe cs.2006.01.001.
14. Torikaiu K, Uwano Y, Nakamori T, Tarora W, Takahashi H. Study on tobacco components involved in the pyrolytic generation of selected smoke constituents. Food Chem Toxicol. 2005;43(4):559-68, http://dx.doi.org/10.1016/j.fct. 2004.12.011.

15. Esteban M, Castaño A. Non-invasive matrices in human biomonitoring: A review. Environ Int. 2009;35(2):438-49, http://dx.doi.org/10.1016/j.envint.2008.09.003.

16. Chelchowska M, Ambroszkiewicz J, Gajewska J, Laskowska-Klita T, Leibschang J. The effect of tobacco smoking during pregnancy on plasma oxidant and antioxidant status in mother and newborn. Eur J Obstet Gynecol Reprod Biol. 2011;155(2):132-8, http://dx.doi.org/10.1016/ j.ejogrb.2010.12.006.

17. Baranowski J, Pochopien G, Baranowska I. Determination of nicotine, cotinine and caffeine in meconium using high-performance liquid chromatography. J Chromatogr B Biomed Sci App. 1998;707(1-2):317-21, http://dx.doi. org/10.1016/S0378-4347(97)00619-1.

18. Gareri J, Klein J, Koren G. Drugs of abuse testing in meconium. Clin Chim Acta. 2006;366(1-2):101-11, http://dx.doi. org/10.1016/j.cca.2005.10.028.

19. Bearer CF. Meconium as a biological marker of prenatal exposure. Ambul Pediatr. 2003;3(1):40-3.

20. Scherer G. Biomonitoring of inhaled complex mixtures Ambient air, diesel exhaust and cigarette smoke. Exp Toxicol Pathol. 2006;58(1):101-24, http://dx.doi.org/10.1016/ j.etp.2005.05.007.

21. Pellegrini M, Marchei E, Rossi S, Vagnarelli F, Durgbansh A, García O, et al. Liquid chromatography/electrospray ionization tandem mass spectrometry assay for determination of nicotine and metabolites, caffeine and arecoline in breast milk. Rapid Commun Mass Spectrom. 2007;21(16): 2693-703, http://dx.doi.org/10.1002/rcm.3137.

22. Demkowska I, Polkowska Ż, Namieśnik J. Application of ion chromatography for the determination of inorganic ions, especially thiocyanates in human saliva samples as biomarkers of environmental tobacco smoke exposure. J Chromatogr 
B Biomed Sci App. 2008;875(2):419-26, http://dx.doi.org/ 10.1016/j.jchromb.2008.09.018.

23. Demkowska I, Polkowska Ż, Kiełbratowska B, Namieśnik J. Application of ion chromatography for the determination of inorganic ions, especially thiocyanates, in human semen samples as biomarkers of environmental tobacco smoke exposure. J Anal Toxicol. 2010;34:533-8, http://dx.doi. org/10.1093/jat/34.9.533.

24. Chan D, Caprara D, Blanchette P, Klein J, Koren G. Recent developments in meconium and hair testing methods for the confirmation of gestational exposures to alcohol and tobacco smoke. Clin Biochem. 2004;37(6):429-38, http:// dx.doi.org/10.1016/j.clinbiochem.2004.01.010.

25. Ostrea EM, Knapp DK, Romero A, Montes M, Ostrea AR. Meconium analysis to assess fetal exposure to nicotine by active and passive maternal smoking. J Pediatr. 1994;124(3):471-6, http://dx.doi.org/10.1016/S0022-34 76(94)70378-7.

This work is available in Open Access model and licensed under a Creative Commons Attribution-NonCommercial 3.0 Poland License - http://creativecommons.org/ licenses/by-nc/3.0/pl/deed.en. 